\title{
Investigating the Break and the Structural Changes of Tax in United States
}

\author{
AliReza Shakibaei ${ }^{1} \&$ Mohammad Reza Ahmadinejad ${ }^{2}$ \\ ${ }^{1}$ Associate Professor of economy, University of Shahid Bahonar, Kerman, Iran \\ ${ }^{2}$ MA student of economy, University of Shahid Bahonar, Kerman, Iran \\ Correspondence: Mohammad Reza Ahmadinejad, MA student of economy, University of Shahid Bahonar, \\ Kerman, Iran. Tel: 98-913-195-8291. E-mail: Ahmadinejad.mr@gmail.com
}

Received: April 8, 2016

doi:10.5539/mas.v10n8p152
Accepted: April 21, 2016

Online Published: June 18, 2016

URL: http://dx.doi.org/10.5539/mas.v10n8p152

\begin{abstract}
Structural alterations has made essential changes in the development of countries' economy, international trading and the expansion of urban centers. Structural changes are defined as an alteration in proportional weight of important parts in the major indices such as the output of governments' expenditure, taxes, etc. Since change in traditional structures of economical factors to new structures is one of the most effective reasons of growth and development in the economy of governments, the attention of governments to influencially important economical factors, and studying the process of changes in important parts of economy such as tax has been considered. So considering the important role of tax in the countries' economy the investigation of changes in the tax structure is of paramount importance, hence in the present study we have examined the structure changes of the types of taxes in America by using the Bai and Perron sequential procedure for the period 1971-2012. The results show that only the corporate tax has faced with the structural changes.
\end{abstract}

Keywords: structural breaks, tax structure changes, bai and perron method, United States

\section{Introduction}

Structural evolutions in the near past have created the significant changes in economic growth of countries, international trade and the expansion of urban centers. Structural change is defined as a change in the relative weight of the important constituents of the macro-economic indicator such as production and government expenses, taxes, imports and exports, population and workforce. One example of this structural change that is done quickly is the transition from the agricultural sector to the production and services one. Another example is the transfer of population from young to older in which the increase of life expectancy has been considerable and also the other example is mutation in technology capacities in the some developing countries.

With a change in the macro structures the tax structure also has exposed to change proportionately. In the non-oil new economy the taxes has an important place, because the states' need to financial credit for performing the duties and responsibilities of providing safety and protection of borders, providing public goods and services, consolidation and so on in the society cause them to act in various ways for providing financial credit and the taxes as one of the most important ways of providing financial credit since the beginning of formation of societies and states have always been considered and investigated; in fact the tax is among the important sources of the state's revenues that is also the most important instrument of implementing the state's fiscal policy and plays an important role in achieving the economic goals such as the social justice, improving income distribution, resource allocation and economic stability.

So due to the very important position of tax in the countries' economy, investigating the trend of changes in the tax structure is of paramount importance; hence in this study we investigate the changes in the tax structure in United States for the period 1971-2012. In this regard the second part has dealt with the literature by examining the conducted researches that have been provided on the structural changes and tax. In the third and fourth section we have clarified and estimated the model and finally conclusion is presented.

\section{Literature}

Hori, Takeo, Ikefuji, Masako \& Kazuo Mino (2012) investigated the structural changes in the model of endogenous two-part growth and that existence of side effects of specific product consumption could be the 
source of structural changes. Under limited circumstances that side effects are the same, structural changes occur. Randall, Michelle (2012) has investigated the structural changes in developing countries and the evolution of the labor market of women since 2008 with assessing the role of change in the workforce demand. Results show the importance of structural change in reducing gender inequality by reducing the demand for workforce for the physical properties. Dennis, Benjamin and N, Iscan Talan (2011) carried out a study entitled "agricultural distortions, structural change and economic growth: A field analysis". The results showed that the polices of agricultural deviation in weak economies could explain the departure from the convergence center and in the sample under study delay considerably their structural changes and economic growth. McMillan, M. \& D. Rodrik (2011) mentioning the importance of economy structure change for achieving development recognize the most important factor of difference between two groups of the successful and unsuccessful countries to be historically the speed of transition of agricultural structure of economy to industrial one. Mu Yi and Zhang J. (2011) by using the three-part model investigated the structural changes in the open economy. Their results showed that there is a relationship between the share of employment, share of expenses sector and net exports from GDP. Lucchese, Matteo (2011) has examined innovation, demand and structural changes for the six largest economies in Europe in the period of 1995-2007. The results show that the structural changes play an important role in the attraction of economic growth. Mertens Karel \& Ravn Morten O. (2013) examined the dynamic effects of personal income and corporate tax changes in the United States; the results show that it is the short-term effects of output of large tax shocks that due to their impact on the labor market and the main constituents of the costs are important for distinguishing the different types of tax. Sivadasan, Jagadeesh and Slemrod Joel (2006) studied the tax law changes, changes in income and the wage inequality measure in the period 1986-1995 for India. They found that there is a quick and comprehensive response by the partner companies for changing the tax law in the form of a significant change of income resulting from profit toward the managed wages. Tuan Minh Le (2012) were studied the tax effort and tax capacity of 110 developed and developing countries over the period 1994 to 2009. The results show that countries with better institutional quality such as quality of the bureaucracy can collect higher tax.

\section{Theoretical Foundations}

By assuming the entry of induction and independent tax and its dependence on income and placement of the total supply instead of the total demand (equality clause), tax is relatively dependent on $\mathrm{Y}$ and the factors of production and moderating parameter of factors of production such as productivity. If the tax is considered as relative, we have:

$$
\frac{T}{Y}=(K, L, Y, A)
$$

In which $\mathrm{K}$ is the capital size and $\mathrm{L}$ the workforce, $\mathrm{Y}$ value added (national income) and $\mathrm{A}$ the productivity coefficient or technology coefficient.

Gordon, Roger and Li, Wei. (2005) from the condition of maximization of social welfare and given that the aim of entering the state and taxation is the maximization of social welfare and with introducing the types of taxes (including capital tax, sale tax, imports tax, tariffs) in this function conclude that:

$$
\begin{gathered}
W=\max _{s_{i}^{*}, \tau_{2}}\left[V\left(p_{1}^{*}, p_{2}^{*}\left(1+\tau_{2}\right), w, r\right)+U\left(\sum_{i} s_{i}^{*} p_{i}^{*} f_{i}^{*}+t_{K} K+\tau_{2} p_{2}^{*} M_{2}\right)\right]=\max _{s_{i}^{*}, \tau_{2}}\left[V\left(p_{1}^{*}, p_{2}^{*}\left(1+\tau_{2}\right), w, r\right)+\right. \\
U\left(\sum_{i} p_{i}^{*}\left(f_{i}-C_{i}\right)\right]
\end{gathered}
$$

In the above equation $\mathrm{V}$ is an indirect benefit that one representative of activity of private sector receives and $\mathrm{U}$ is a function of the total tax revenue that is the supplier of public expenses. Gordon believes that for identifying the effectiveness of tax we can argue whether the companies for financing act through banks or use the internal resources. In the above equation the capital is taxed with $t_{K}$ rate, while any $t_{K}$ of industry is faced conditionally with a maximum rate of sale tax $s_{1}^{\max }<s_{2}^{\max }$ and $s_{i}^{*}$. Suppose that a country exports the first goods and imports the second goods. Goods 2 is imported with a tariff of $\tau_{2}$ rate, while export of the first goods is done without tax.

We identify imports of the second goods by $M_{2}$ and domestic consumption of two goods by $\mathrm{C}_{\mathrm{i}}$. The domestic consumption prices are equal to $\mathrm{p}_{1}^{*} \& \mathrm{p}_{2}^{*}\left(1+\tau_{2}\right)$, while the prices that domestic producers are faced with them is equal to $p_{1}^{*}\left(1-s_{1}^{*}\right)$ and $p_{2}^{*}\left(1+\tau_{2}\right)\left(1-s_{1}^{*}\right)$. To simplify the notation $f_{1}^{*} \equiv f_{1}$ and $f_{2}^{*} \equiv\left(1+\tau_{2}\right) f_{2}$ suppose $\mathrm{i}$ for domestic production in industry as well as the total capital, $\mathrm{r}$ for domestic interest rate and $\mathrm{w}$ for the internal wage rate. Considering the total internal budget limitation the state tax profit is equal to the value of domestic consumption. The state maximizes this with limitation of $s_{i}^{*}<s_{i}^{m}$ for each given $t_{K}$.

The constituted condition of the first order for $t_{K}$ is as following: 


$$
U^{\prime}\left(\sum_{i} p_{i}^{*}\left(\frac{\partial f_{i}}{\partial \tau_{2}}-\frac{\partial C_{i}}{\partial \tau_{2}}\right)\right)=V_{I}\left(p_{2}^{*} C_{2}-K \frac{\partial r}{\partial \tau_{2}}-L \frac{\partial w}{\partial \tau_{2}}\right)=V_{I} p_{2}^{*}\left(M_{2}+s_{2}^{*} f_{2}\right)
$$

Where $V_{I}$ measures the ultimate utility of income and $\mathrm{L}$ does the total workforce. The collective budget of individuals is equal to:

$$
p_{1}^{*} C_{1}+p_{2}^{*}\left(1+\tau_{2}\right) C_{2}=p_{1}^{*}\left(1-s_{1}^{*}\right) f_{1}\left(L-L_{2}, K-K_{2}\right)+p_{2}^{*}\left(1+\tau_{2}\right)\left(1-s_{1}^{*}\right) f_{2}\left(L_{2}, K_{2}\right)-t_{K} K
$$

Which connotes:

$$
\begin{gathered}
\left(\sum_{i} p_{i}^{*}\left(\frac{\partial f_{i}}{\partial \tau_{2}}-\frac{\partial C_{i}}{\partial \tau_{2}}\right)\right)=p_{2}^{*}\left(M_{2}+s_{2}^{*} f_{2}\right)+\tau_{2} p_{2}^{*} \frac{\partial C_{2}}{\partial \tau_{2}}+\frac{s_{1}^{*}}{1-s_{1}^{*}}\left(w \frac{\partial L}{\partial \tau_{2}}+\left(r+t_{K}\right) \frac{\partial K}{\partial \tau_{2}}\right)+t_{K} \frac{\partial K}{\partial \tau_{2}}+p_{2}^{*} \frac{\partial f_{2}}{\partial \tau_{2}}(1- \\
\left.\frac{\left(1+\tau_{2}\right)\left(1-s_{2}^{*}\right)}{1-s_{1}^{*}}\right)
\end{gathered}
$$

By substituting equation (3) with equation (5) the following result is achieved:

$$
\left(1-\frac{V_{1}}{U^{\prime}}\right)\left(M_{2}+s_{2}^{*} f_{2}\right)+\tau_{2} p_{2}^{*} \frac{\partial C_{2}}{\partial \tau_{2}}+p_{2}^{*} \frac{\partial f_{2}}{\partial \tau_{2}}\left(1-\frac{\left(1+\tau_{2}\right)\left(1-s_{2}^{*}\right)}{1-s_{1}^{*}}\right)+t_{K} \frac{\partial K}{\partial \tau_{2}}+\frac{s_{1}^{*}}{1-s_{1}^{*}}\left(w \frac{\partial}{\partial \tau_{2}}+\left(r+t_{K}\right) \frac{\partial K}{\partial \tau_{2}}\right)=0
$$

The above function can be written as follows:

$$
\left(\alpha_{1} M_{2}+\alpha_{2} f_{2}\right)+\beta\left(\frac{\partial C_{2}}{\partial \tau_{2}}\right)+\varphi\left(\frac{\partial f_{2}}{\partial \tau_{2}}\right)+\gamma\left(\frac{\partial K}{\partial \tau_{2}}\right)+\left(\mu_{1} \frac{\partial L}{\partial \tau_{2}}+\mu_{2} \frac{\partial K}{\partial \tau_{2}}\right)=0
$$

That coefficients in the above equation are as follows:

$\alpha_{1}=\left(1-\frac{V_{1}}{U^{\prime}}\right), \alpha_{2}=s_{2}^{*}\left(1-\frac{V_{1}}{U^{\prime}}\right), \beta=\tau_{2} p_{2}^{*}, \varphi=p_{2}^{*}\left(1-\frac{\left(1+\tau_{2}\right)\left(1-s_{2}^{*}\right)}{1-s_{1}^{*}}\right), \gamma=t_{K}, \mu_{1}=\frac{s_{1}^{*}}{1-s_{1}^{*}} w, \mu_{2}=\frac{s_{1}^{*}}{1-s_{1}^{*}}(r+$

$\left.t_{K}\right)$

In equation (6) the first phrase measures the net welfare effects from the bulk transfer of specific amount by residents to state that indicates the total tax. Also the second, fourth and fifth phrases are tax on consumption, capital and sale. The third phrase measures the effect of net efficiency caused by changes in the composition of production; so changes function of changes in the efficiency (here per capita income) can be presented as follows that according to Gordon model is a function based on the types of tax:

$$
E=f\left(T_{i}\right)
$$

Theoretically there are different arguments about the importance of structural change for economic growth and the relationship between these two phenomena out of which we can refer to cases such as hypothesis of multi-sectoral economy, the income attraction and the law of parasite, capital deepening and innovation, higher allocation and growth, industrialization and the hypothesis of suitable or normal structure. One of the important foundations of the hypothesis of the effect of structural changes on the economic growth and development is that the structural changes cause the allocation of resources to sectors with the higher productivity; this situation helps the growth. Therefore, if structural change leads to a more complete and better exploitation, then the structural changes is seen as another source of growth (Chenery, 1988; Eltejayi, 2008). Hence, economists introduced the structural changes as a source of the economic growth. If the technological progress is large enough, the average propensity to save and national income will increase naturally (Lightner, 2000). Iginger (2001) with a mention to the hypothesis of norm structure suggests that if any income level creates a specific industrial structure, it can be hypothetically calculated a norm structure dependent on the income. It is expected the countries that exhibit this norm structure, in other words have the natural structure consistent with income level, they can grow more rapidly, while the countries that do not have the natural structure consistent with the income level will have slower growth. The hypothesis of consistency of structure with the level of income in the Petroleum Exporting Countries that the vast oil revenues have caused the increase of their per capita income has very importance. In general, structural changes can be occur by various reasons such as war, economic adjustment, changes in the exchange rate regime, change of pricing system etc. that depend on year of breakpoint. In the following we provide descriptions about the structural break and its identification and determination.

If the change in the process of variables due to conditions and circumstances prevailing on economic variables takes place alongside with changes in the parameters of model, or in other words if in the reliability of the parameters of a model a disorder occurs, these changes are called the structural break (Marzban \& Nejati, 2009).

A statistic test of structural break can usually be divided into four categories: 
1) Certain breakpoints against uncertain breakpoints.

2) A single break against multiple breaks.

3) The univariate relationship against the multivariate relationships.

4) The stable variables against unstable variables (Madala \& Kim, 1998).

Perron is an economist that has done several studies in relation to structural breaks. He believes that most of macroeconomic time series are not characterized as having a unit root. He says that the existence of unit root that is confirmed in most of variables of macroeconomic time series may be caused by lack of attention to major structural breaks in the process of these variables. For this purpose the tests of Dicky-Fuller (DF) and generalized Dickey-Fuller (ADF) are used as the most common stationary test methods of the time series. In the studies of Perron (1989 \& 1997) and Rappoport \& Riechilin (1998) the levels of redirection has been determined as exogenous.

\section{Tax System of America}

United States of America include a federal republic with state and autonomous local states. The tax laws in this country are applied based on each of these levels. United States have one of the most progressive tax systems in the industrialized world. The taxable income has been set under laws of tax account and accounting principles and includes any income achieved from any source. Many costs related to the business reduce the taxable income; state tax laws are different from federal laws and different types of levied tax on each level are different due to the limitations of the constitution. In the following we investigate several important taxes in the US.

\subsection{Income Tax}

Net income tax of individuals and companies is levied by federal and provincial state and some local states. The income subject that tax is levied for it is specified by tax law not by the accounting principles and almost it includes all incomes from whatever source. Main channels of paying income tax include the following:

* Staff, tax is deducted monthly from their income.

* The self-employed, payment of 3 months of the approximate tax.

* Unemployed individuals who have enough income to pay taxes 3 months.

* Alternative minimum tax, for those who attempt to reduce their share of tax that is payable approximately.

The federal income tax rate in US is from $15 \%$ to $35 \%$. Of course this rate could be different based on laws in the different provinces.

\subsection{Salary and Wage Tax}

This tax is levied in the federal and state level and includes the social security, unemployment tax and medical care tax that is levied on both workers and employers with a combined rate of $15.3 \%$ (13.3 in 2011). The social security tax is levied on individuals if the wage amount reaches to $106,800 \$$ from 2009 to 2011 . This tax is levied as a percentage of the taxable salaries. For 2009 the maximum of ordinary tax per each worker was determined less than $1,000 \$$.

\subsection{Assets Tax}

Assets tax is levied by the federal and provincial state based on market value of individuals' assets. This type of tax is levied on individuals' real estate and commercial assets. The assets tax rate is very broad and different.

\subsection{Sale and Consumption Tax}

This tax is levied on the retail price of many goods and services provided by provincial states and individuals. Sale tax rate is varied between $1 \%$ and $16 \%$ that this amount of varying is provided based on various goods and services.

\subsection{Income Tax and Customs Tariff}

This tax is levied on many imported goods to the United States. This taxes should be paid before the goods are imported legally. The rate of this tax is varied between $0 \%$ to $20 \%$ based on the type of imported goods.

\subsection{Tax on Earning Capital}

The capital obtained from the sale of assets is taxable. The term of the net capital earning means the capital interest achieved in a long-term period of one year that the amount of capital loss is deducted.

The maximum of tax rate is $15 \%$. 
Amon the other taxes in the United States it can refer to the dividend tax, inheritance tax, tax on amount of impact on the environment, tax on oil products, tax on luxury goods, tax on investment etc. The number of taxes in the United States includes about 50 different tax types in the major sectors of this country.

In this study all taxes mentioned in four sectors of income tax, wealth, sale and corporate tax have been considered (tax on imports due to lack of sufficient information has been deleted) and finally all taxes in the form of total are included and investigated.

\section{The model Estimation}

Since per capita income is one of the most important and macro indicators of economy, a lot of data and factors are influencing on this variable. With a study and analysis of conducted previous studies about per capita income and the various estimates that have been done on this indicator, two important effective indicators of per capita net capital and state expenses to GDP can be introduced and according to mentioned themes in the theoretical foundations, the final function of per capita income that is the desired function of this research is presented as follows:

$$
E=f\left(T_{i}, \frac{G F C}{P O P}, \frac{G}{G D P}\right)
$$

In the above equation $E \cdot \frac{G F C}{P O P}$ and $\frac{G}{G D P}$ represent respectively the per capita income, per capita net of the capital stock and ratio of state's expenses to gross domestic product. Also T represents a variety of tax rates which include: The total tax ratio to gross domestic product, ratio of income tax, corporate, wealth and sale of goods tax that each one is estimated separately in an equation. In addition America's data in the period 1971-2012 are used for estimating.

Also for estimating the model, investigating and determining the structural break the GUASS software has been used.

The test of structure break in the linear regression models took place first by Chow (1960) and Quant (1958), then by Brown, Durbin and Evans (1975). In these studies the test of structure break is done exogenously in a predetermined point; but since 1990 other methods for testing the structural break have been used. In these methods the desired test is done endogenously in a undetermined or non-predetermined point or points. These methods are presented by Andrews (1993), Andrews and Ploberger (1994) Andrews for the one break state and by Lee and Ploberger (1996) Liu, Wu and Zidek (1997) Bai and Perron $(1998,2003)$ for the multi break state. In the present research based on the method of Bai and Perron $(1998,2003)$ the number and place of breakpoints were estimated endogenously by using linear regression model. Yao (1988) for calculating the structural breaks proposes the use of Bayesian information criterion (BIC), while Liu et al. (1997) offer the modified Schwartz criterion (LWZ). Perron (1997) provides a simulated study about the behavior of these two information criteria and the criterion of AIC in the field of estimation of number of changes in the process function of a set and series concerning the existence of serial and sequential correlation and relationship. First it is assumed that there is a number $(1+m)$ of the policy regime, as a result we have $m$ structural change. So it has a linear regression with $\mathrm{m}$ break and $(1+\mathrm{m})$ parameter that their statistical representation is as follows:

$$
\begin{gathered}
y_{t}=x_{t}^{\prime} \beta+z_{t}^{\prime} \delta_{1}+u_{t} t=1, \ldots, T_{1} \\
\cdot \\
\cdot \\
y_{t}=x_{t}^{\prime} \beta+z_{t}^{\prime} \delta_{m}+u_{t} t=T_{1}+1, \ldots, T_{2} \\
y_{t}=x_{t}^{\prime} \beta+z_{t}^{\prime} \delta_{m+1}+u_{t} t=T_{m}+1, \ldots T
\end{gathered}
$$

$\mathrm{T}_{1}, \mathrm{~T}_{2}, \ldots, \mathrm{T}_{\mathrm{m}}$ is the undetermined structural breakpoints (non-predetermined), $\mathrm{y}_{\mathrm{t}}$ the dependent variable in time $\mathrm{t}$, $z_{t}$ with dimensions $(\mathrm{q} \times 1)$, the vector of independent variables with variable coefficients in the different regimes, $x_{t}$ with dimensions $(\mathrm{p} \times 1)$ ، vector of independent variables with the constant coefficients, $\beta$ the vector of constant coefficients, $(\mathrm{m}+1, \ldots, 2,1=\mathrm{j}) \delta \mathrm{j}$ the vector variable coefficients and $\mathrm{u}_{\mathrm{t}}$ is the error in the time t. $\mathrm{P}=0$ is the model of pure structural break, this means that all coefficients change with $\delta \mathrm{j}$, otherwise $(\mathrm{p}\rangle 0)$ is a model with partial break, because only $\delta \mathrm{j}$ changes. It is assumed that $\beta$ is constant and $\delta \mathrm{j}$ changes with the regime change. The main objective is that we can estimate the coefficients and undetermined breakpoints of regression 
$\left(\beta, \delta_{1}, \ldots, \delta_{\mathrm{m}+1}, \mathrm{~T}_{1}, \mathrm{~T}_{\mathrm{m}}\right)$ when $\mathrm{T}$ observation from $\left(\mathrm{y}_{\mathrm{t}}, z_{t} \cdot x_{t}\right)$ is obtained.

The statistics proposed by Bai and Perron in order to identify and estimate the breakpoints are as follows:

1) The test of $\sup \mathrm{F}_{\mathrm{T}}(\mathrm{k})$ with assuming zero $(\mathrm{m}=0)$ means the lack of structural change and opposite hypothesis $(\mathrm{m}=\mathrm{k})$ means the existence $\mathrm{k}$ break in the model.

2) The tests of UDmax and WDmax that WDmax is the weight type of Udmax. The weight used in these tests is dependent on the number of explanatory variables and significance level of test. The zero hypothesis in these two tests is the lack of structural break $(\mathrm{m}=0)$ and the opposite hypothesis is the uncertain number of break with the maximum number $m$ (Marzban \& Nejati).

According to a study of Bai and Perron (2003) we conclude that if a structural break occurs in the period under investigation, this break is a structural change when the second regime coefficient has a considerable difference with the first regime coefficient. If two or more breaks occur in a period (in this study due to the period of 42 years there's eventually two breaks), it can be said a structural change has happened when the second and third regime coefficients have a significant difference with the first regime coefficient, or if the first and second regime coefficient are close together, the third regime coefficient is different from them. Now if the second regime coefficient has a considerable difference from the first regime coefficient, but if the third the regime coefficient has a small difference from the first regime coefficient, then a structural change has not occurred, because the movement process of the variable under investigation has went again near to the original state; this means that the first break that has made to create the second regime, it has been only a short-term unstable change that can be due to fluctuations of an effective variable the shocks that in the economy have occurred in that period.

Table 1. Results of UDmax, WDmax and SupFT tests at a significance level of 5\%

\begin{tabular}{llllllll}
\hline $\begin{array}{l}\text { Tax on Goods } \\
\text { and Services }\end{array}$ & $\begin{array}{l}\text { Tax on } \\
\text { Wealth }\end{array}$ & $\begin{array}{l}\text { Tax on } \\
\text { Corporates }\end{array}$ & $\begin{array}{l}\text { Tax on } \\
\text { Income }\end{array}$ & $\begin{array}{l}\text { Total } \\
\text { Tax }\end{array}$ & $\begin{array}{l}\text { Critical } \\
\text { Value }\end{array}$ & Test & Break \\
\hline $\mathbf{3 8 . 0 2 3}$ & 22.706 & 32.719 & 28.692 & 39.488 & 8.01 & UDmax & 1 \\
$\mathbf{3 8 . 0 2 3}$ & 22.706 & 32.719 & 28.692 & 39.488 & 8.69 & WDmax & \\
$\mathbf{3 8 . 0 2 3}$ & 22.706 & 32.719 & 28.692 & 39.488 & 7.86 & SupF $_{\mathrm{T}}$ & \\
$\mathbf{4 . 9 8}$ & 14.43 & 24.278 & 2.642 & 27.375 & 5.8 & SupF $_{\mathrm{T}}$ & 2 \\
\hline
\end{tabular}

Source: Estimate calculation

Based on the results table 1 UDmax and WImax tests indicate the break in the trend of a variety of taxes. SupFT test show two breaks that both of them are significant in a variety of taxes.

Table 2. Results of BIC test at significance level of 5\%

\begin{tabular}{lllllllll}
\hline Taxes & & Intercept & $\begin{array}{l}\text { The } \\
\text { regime }\end{array}$ & $\begin{array}{l}\text { first } \\
\text { regime }\end{array}$ & $\begin{array}{l}\text { second } \\
\text { regime }\end{array}$ & third & Number $\begin{array}{r}\text { of } \\
\text { Break }\end{array}$ \\
\hline Total & Coefficient & 0.555 & -0.573 & -0.525 & -0.545 & 2 \\
Income & Coefficient & -1.146 & -0.07 & -0.034 & ---- & 1 \\
Corporates & Coefficient & -4.313 & 0.09 & 0.143 & 0.092 & 2 \\
Wealth & Coefficient & -1.253 & 0.024 & 0.078 & ---- & 1 \\
$\begin{array}{l}\text { Goods } \\
\text { Services }\end{array}$ & and & Coefficient & -1.676 & 0.192 & 0.239 & --- & 1 \\
\hline
\end{tabular}

Source: Estimate calculation

Table 3. Results of LWZ test at significance level of 5\%

\begin{tabular}{llllllll}
\hline Taxes & Intercept & $\begin{array}{l}\text { The } \\
\text { regime }\end{array}$ & $\begin{array}{l}\text { first } \\
\text { regime }\end{array}$ & $\begin{array}{l}\text { second } \\
\text { The } \\
\text { regime }\end{array}$ & $\begin{array}{r}\text { third } \\
\text { Number } \\
\text { Break }\end{array}$ \\
\hline Total & Coefficient & 0.631 & -0.384 & -0.338 & ----- & 1 & \\
Income & Coefficient & -1.146 & -0.07 & -0.034 & ---- & 1 \\
Corporates & Coefficient & -1.31 & -0.036 & 0.027 & ---- & 1 \\
Wealth & Coefficient & -1.253 & 0.024 & 0.078 & ---- & 1 & \\
\hline
\end{tabular}




\begin{tabular}{|c|c|c|c|c|c|c|c|}
\hline $\begin{array}{l}\text { Goods } \\
\text { Services }\end{array}$ & and & Coefficient & -1.676 & 0.192 & 0.239 & ----- & 1 \\
\hline
\end{tabular}

Source: Estimate calculation

Based on the tables (2) and (3) it can be concluded that the results of two tests for income taxes, sale and wealth tax are similar and all have had one break, but in the BIC test the corporate tax and the total tax have exposed to two breaks.

Table 4. Results of Bai and Perron test (sequential procedure) at a significance level of 5\%

\begin{tabular}{|c|c|c|c|c|c|c|c|c|}
\hline \multirow[t]{2}{*}{ Taxes } & & \multirow[t]{2}{*}{ Intercept } & \multirow{2}{*}{$\begin{array}{l}\text { The first } \\
\text { regime }\end{array}$} & \multirow{2}{*}{$\begin{array}{l}\text { The } \\
\text { second } \\
\text { regime }\end{array}$} & \multirow{2}{*}{$\begin{array}{l}\text { The third } \\
\text { regime }\end{array}$} & \multirow[b]{2}{*}{$\begin{array}{r}\text { Number of } \\
\text { Break }\end{array}$} & \multicolumn{2}{|c|}{ Details of break } \\
\hline & & & & & & & $\begin{array}{r}\text { Number } \\
\text { of Year }\end{array}$ & Year \\
\hline Total & Coefficient & 0.631 & -0.384 & -0.338 & $\begin{array}{ll}---- \\
\end{array}$ & 1 & 18 & 1988 \\
\hline Income & Coefficient & -1.146 & -0.07 & -0.034 & ----- & 1 & 18 & 1988 \\
\hline Corporates & Coefficient & -1.31 & -0.036 & 0.027 & ----- & 1 & 18 & 1988 \\
\hline Wealth & Coefficient & -1.253 & 0.024 & 0.078 & ----- & 1 & 18 & 1988 \\
\hline $\begin{array}{l}\text { Goods and } \\
\text { Services }\end{array}$ & Coefficient & -1.676 & 0.192 & 0.239 & ----- & 1 & 18 & 1988 \\
\hline
\end{tabular}

Source: estimate calculation

According to the results of the table (4) America in all taxes has been faced only with one structural break that the year of break also is same for all of them. But these breaks have not led to the structural changes in all taxes and only the corporate tax is exposed to changes in the tax structure.

\section{Conclusion}

Structural evolutions in near past have created important changes in the countries' economic growth, international trade and the expansion of urban centers. Since the change in the traditional structure of economic factors into new structures is one of the main reasons for the growth, dynamism and economic development of countries, the states' attention to important factors affecting the economy and investigating the changes trend of the important constituents of the economy such as tax are of importance. Hence, the present study has discussed the breaks and structure changes of taxes in United States of America for the period 1971-2012. In order to investigate the existence of the structural change or lack of structural change we have investigated the structural breaks in the movement process of a variety of taxes; an investigation of the breaks were performed by various tests and GUAAS software. Based on the results of the BIC test the corporate tax and the total tax have been faced with two structure breaks and other taxes with one structural break. The LWZ test about taxes on income, wealth and sale confirms the results of BIC test, but Perron provides a simulated study of the behavior of these two information criteria and the criterion of AIC for estimating the number of changes in the function of the trend of one set and series in relation with a serial and sequential correlation and relationship; the results show that the BIC test for the total tax and corporate tax is different and each one has exposed to one structural break. The results of Bai and Perron test show the all taxes in 1988 have been exposed to a structural break, but these breaks have not led to the structural changes and only the corporate tax has been faced with the structural changes.

\section{References}

Agnar, S. (1976). Optimal Taxation an introduction to the literature. Journal of Public Economics, 6, 37-54. http://dx.doi.org/10.1016/0047-2727(76)90040-2

Aiginger, K. (2001). Speed of Change and Growth of Manufacturing. Federal Ministry for Economic Affairs and Labour Department for Industry, 2, 1-43.

Bai, J., \& Perron, P. (1998). Estimating and Testing Linear Models with Multiple Structural Changes. Econometrica, 66, 47-78. http://dx.doi.org/10.2307/2998540

Bai, J., \& Perron, P. (2003a). Computation and Analysis of Multiple Structural Change Models. Journal of Applied Econometrics, 18, 1-22. http://dx.doi.org/10.1002/jae.659

Bai, J., \& Perron, P. (2003b). Critical Values for Multiple Structural Change Tests. Econometrics Journal, 6, 
72-78. http://dx.doi.org/10.1111/1368-423X.00102

Banerjee, A., Lumsdaine, R. L., \& Stok, J. H (1992). Recursive and Seqential Test of Unit Root and Trend Break Hypothesis. Journal of Business and Economic Statistic, 10, 271-287. http://dx.doi.org/10.3386/w3510

Chow, G. C. (1960). Tests for Inequality between Sets of Coefficients in Two Linear Regression. Econometrica, 28, 591-605. http://dx.doi.org/10.2307/1913018

Christiano, L. J. (1992). Searching for Breaks in GDP. Journal of Business and Economics, 10, 273-250.

Dennis, B., \& Talan, I. (2011). Agricultural Distortions, Structural Change, and Economic Growth: A Cross-Country Analysis. American Journal of Agricultural Economics, 93(3), 881-902. http://dx.doi.org/10.1093/ajae/aar011

Gordon, R., \& Wei, L. (2005). Tax Structures in Developing Countries: Many Puzzles and a Possible Explanation. NBER Working Paper.

Hori, T., Ikefuji, M., \& Kazuo, M. (2012). Conformism and Structural Change. Discussion Paper 825.

Inoue, T., Atsushi, M., \& Hitoshi, O. (2013). The Contagion of the Greek Fiscal Crisis and Structural Changes in the Euro Sovereign Bond Markets. Policy Research Institute. Ministry of Finance, Japan, Public Policy Review, 9(1), 171-202.

Kohansal, M. R., \& Iravani, S. (2014). Investigating the uncertain multiple structural breaks in agricultural prices (Case Study of livestock products). Research-book of Agricultural Economics, 2(6), 87-101.

Liu, J., Wu, S., \& Zidek, J. V. (1997). On segmented multivariate regressions. Statistica Sinica, 7, 497-525.

Lucchese, M. (2011). Innovation, Demand and Structural Change in Europe. Working Paper_EMS.

Marzban, H., \& Nejati, M. (2010). Structural break in the lasting of inflation and Phillips curve in Iran. Quarterly of Economic Modeling, 2(8), 1-26.

McMillan, M., \& Rodrik. D. (2011). Globalization, Structural Change and Productivity Growth. Development Strategies and Governance. Tufs University and Harvard Kennedy School.

Mertens, K., \& Morten, R. (2013). The Dynamic Effects of Personal and CorporateIncome Tax Changes in the United States. American Economic Review, 103(4), 1212-1247. http://dx.doi.org/10.1257/aer.103.4.1212

Moshiri, S., \& Ebrahim, D. (2008). Effects of structural changes on economic growth in newly industrialized countries. Quarterly of Economic Researches in Iran, 36, 85-113.

Moshiri, S., \& Ebrahimi, E. (2012). A comparative study of long-term trend of the structural changes in Iran's economy compared with newly industrialized economies, comparative economics. Institute for Humanities and Cultural Studies, 1, 175-222.

Mu, Y. K., \& Zang, J. (2001). Structural Change in an Open Economy. Journal of Monetary Economics, 60(6), 667-682. http://dx.doi.org/10.1016/j.jmoneco.2013.06.002

Perron, P. (1989). The great crash, the oil price shock, and the unit root hypothesis. Econometrica, 4, 1361-1401. http://dx.doi.org/10.2307/1913712

Perron, P. (1997). Further evidence on breaking trend functions in macroeconomic variables. Journal of Econometrics, 2, 355-385. http://dx.doi.org/10.1016/S0304-4076(97)00049-3

Quant, R. (1960). Tests of the hypothesis that a linear Regression Obeys two separate regimes. Journal of the American Statistical Association, 55, 324-30. http://dx.doi.org/10.1080/01621459.1960

Randall, M. (2012). Structural Change in Developing Countries: Has it Decreased Gender Inequality? Working Paper Series. http://dx.doi.org/10.1016/j.worlddev.2012.10.005

Rappoport, P., \& Reichilin, L. (1998). Segmented Trends and Nonstationary Time Series. Economic Journal, 99, 77-168. http://dx.doi.org/10.2307/2234078

Samadi. A., Ali, H., \& Ahmadi, K. (2005). Inflation, productivity and structural break. experimental evidences from economics. Quarterly of Economic Researches in Iran, 27, 65-87.

Sivadasan, J., \& Joel, S. (2006). Tax Law Changes, Income Shifting and Measured Wage Inequality: Evidence from India. National Bureau of Economic Research, 12240, 1-42. http://dx.doi.org/10.3386/w12240

Syrquin, M. (1986). Growth and Structural Change in Latin America since 1960: A Comparative Analysis. Economic Development and Cultural change, 3, 433-454. http://dx.doi.org/10.1086/451544 
Tuan, M. L., Moreno-Dodson, B., \& Nihal, B. (2012). Tax Capacity and Tax Effort: Extended Cross-Country Analysis from 1994 to 2009. Policy research working paper. http://dx.doi.org/10.1596/1813-9450-6252

Yao, Y. C. (1988). Estimating the number of change-points via Schwarz' criterion. Statistics and Probability, 6, 181-189. http://dx.doi.org/10.1016/0167-7152(88)90118-6

Zivot, E., \& Andrews, D. (1992). Further evidence on the great crash, the oil price shock, and the unit root hypothesis. Journal of Business and Economic Statistics, 10, 936- 954.

\section{Copyrights}

Copyright for this article is retained by the author(s), with first publication rights granted to the journal.

This is an open-access article distributed under the terms and conditions of the Creative Commons Attribution license (http://creativecommons.org/licenses/by/3.0/). 